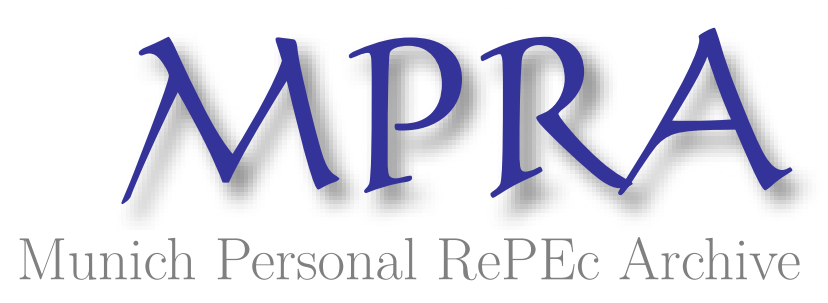

\title{
The real thing: a profile of the coca cola company
}

\author{
Hartogh, Matthew \\ University of California
}

1 January 2007

Online at https://mpra.ub.uni-muenchen.de/5616/

MPRA Paper No. 5616, posted 06 Nov 2007 UTC 


\section{It's Still The Real Thing}

\section{A Profile of the Coca-Cola Company}

Matthew Hartogh

GBUS 600

May 1, 2002 
$\underline{\text { Introduction }}$

The Coca-Cola Company of Atlanta, Georgia is the world's largest provider of carbonated soft drinks with an over 50\% market share worldwide. Atlanta pharmacist John Pemberton created the drink in 1886 as a fountain beverage which contained syrup and water, and the extract of kola nuts and coca leaves. By 1898, the beverage was available at drug store counters in all states as well as Canada and Mexico. ${ }^{1}$

\section{$\underline{\text { Brand Recognition }}$}

Today the flagship Coca-Cola Classic (now without cocaine) is the world's most popular soft drink and along with other Coke products is available in over 200 countries. 1.1 billion servings of Coca-Cola beverages are served every single day. More importantly, the beverage which defined the carbonated cola category continues to maintain strong brand recognition everywhere. The trademark coke bottle or red can with the Coca-Cola wave device, whether written in Hindi, Chinese, or Hebrew, is ubiquitous and is universally recognized by nearly everyone, whether literate or not, in places where the cross of the Christian church has not even been seen. ${ }^{2}$ Truly, Coca-Cola is an American business success story.

\section{$\underline{\text { Competition }}$}

In its core competency, the Coca-Company has only one serious competitor, the PepsiCo Company, maker of Pepsi-Cola. Current market share of the two companies in the United States stands at $43.7 \%$ for Coca-Cola against $31.6 \%$ for PepsiCo. ${ }^{3}$ British firm Cadbury Schweppes comes in third in the American market with its 7UP and Dr. Pepper brands but does not have a head to head cola competitor for Coca-Cola. Supermarket "private label" cola brands are a substitute beverage for the big two but in terms of dollar 
sales, they do not cut greatly into their market share. According to the Beverage Digest 2001 survey, the top 4 brands continue to be Coke Classic, with a U.S. market share of 19.9\%, Pepsi-Cola, with 13.2\%, followed by Diet Coke with $8.8 \%$ and Mountain Dew (a PepsiCo product) with $6.9 \%{ }^{4}$

In recent years, the competition between the top two firms has been vigorous and has been played out for all of us to see on television, in supermarket shelf space, in school lunchrooms and at sports stadiums across the country. One factor driving the intensity of competition between the cola giants has been the flat or declining consumption of carbonated soft drinks (CSDs) in recent years. A changing public taste oriented toward ostensibly lighter and healthier sports drinks, teas, and single serve bottled waters has left the big two scrambling to chip out market share in the increasingly fragmented beverage field. ${ }^{5}$

While overall company market share has remained relatively constant between the big two over the last decade, the Coca-Cola Company has had to struggle not to lose ground to its arch-rival. Last year was not a good one for Coke in which it lost market share to Pepsi. ${ }^{6}$ In addition, the Wall Street Journal reported that this was the third straight year in a row that Coca-Cola has slipped in market share. A 0.1 or $0.2 \%$ decline in share for Coke brands may not sound like much but it adds up to a large sum in a company with over $\$ 20$ billion in annual revenues. ${ }^{7}$ This trend has been noticed by the financial press and Wall Street insiders alike and has depressed the price of Coca-Cola stock to $\$ 53$ a share from its high of $\$ 83$ in the early 1990 's. This is recorded in my SWOT analysis of the company in which a key weakness is listed as weak share price and a key external threat is listed as the perceived strength of PepsiCo's financial position. ${ }^{8}$ 
Strategy into the Future

In a recent interview, I asked Diana Lopez, route manager at the Coca-Cola Bottling Company of Sylmar, California, several questions related to Coke's forward looking strategy and how it plans to position itself in the market. She was especially enthusiastic about new products from the company like Powerade, a sports drink which is gaining in popularity. She related that Powerade and Dasani Water, Coke's entry in that category, are doing very well in machine, convenience, and supermarket sales in southern California. When I asked about how Classic Coke was doing and whether Pepsi posed a challenge to its position, her answer was that "Coke has a very strong following, as it always has and [people tell her] that Coca-Cola's taste is what sells the product. And small store owners tell me, especially in Latino neighborhoods that the Coke brand means quality to them." According to Ms. Lopez, Coca-Cola intends to build upon its success and popularity as the original cola drink which is "loved by consumers everywhere." In the soft-beverage working group, we have indeed identified this feature, differentiation, as key to Coke's historical and continuing success. "If it ain’t broke, don't fix it," was the lesson of the company's ill-fated experiment with "New Coke" in the 1980's.

Moving ahead, Coca-Cola's forward-looking strategy is to position itself in the non-carbonated sector of the soft drink market and take advantage of changing consumer tastes. Since taking over at the helm two years ago, CEO Douglas Daft has endeavored to accomplish this as well as to cut costs so that a leaner Coca-Cola can produce better numbers on the bottom line. In the last two years he has slashed nearly 30,000 from the workforce. In addition, he has placed renewed emphasis on "thinking locally, acting 
locally." This initiative has led to the transfer of quite a few executives from Atlanta to field offices around the country with the mission to feel the pulse of local consumers and serve them better. ${ }^{10}$ Daft has not always found his reform efforts smooth sailing, however. Unlike the legendary Robert Goizueta who steered Coke through its most successful years in the late ' 80 s and early ' 90 s, Mr. Daft has not been given unconditional support by the board of directors. Specifically, Warren Buffet, whose Berkeshire Hathaway has a major share of Coca-Cola stock, demonstrated that he may keep Daft on a short leash by vetoing Daft's bid to acquire Quaker Oats last year. ${ }^{11}$

\section{Legal and Regulatory Issues}

As the multi-billion dollar market leader in the soft-drink world, the Coca-Cola Company is burdened with the strengths and weakness of empire. The company will continue to be held to close scrutiny, both legal and financial. Any attempt to use Coke's enormous market power to leverage strategic advantage in the marketplace will be met by resistance from competitors as well as regulatory authorities. Take, for example a case in which the company was sued for requiring exclusive advertising agreements with local supermarkets in Texas and was required to pay a hefty fine and divest itself of

distribution rights for Dr. Pepper in that jurisdiction. ${ }^{12}$

\section{$\underline{\text { Forecast }}$}

Wall Street analysts have been reporting for some time on the doldrums that Coca-Cola has found itself in the last few years. After the untimely passing of Mr. Goizueta, who led Coke through a period of unprecedented growth and financial success in the ' 80 s and early ' 90 s, the company has drifted for the last few years with 
disappointing earnings and unimpressive efforts to distinguish itself in a market where cola has shown slow or no growth.

New CEO Douglas Daft has shown initiative in repositioning the company to take advantage of the changing consumer tastes we have discussed above. In addition, his cost-cutting moves promise to tighten up the bottom line at a company which has been described as an "enormous bureaucracy."13

The news appears to be brightening up. The L.A. Times reports that Coke expects to show a $9 \%$ earnings gain in the quarterly report due out soon. Also, the stock price, which has been slipping over the last 5 years, is showing rebound over the last few months. This may be in large part due to the resurgent U.S. economy, but let us not forget that Coca-Cola made over $\$ 4$ billion in profit last year. ${ }^{14}$ Further, while Coke has had to skirmish with Pepsi in the American market, it is still dominant overseas. On the positive side of my SWOT analysis, I identify management as a key internal strength. Overseas markets, where Coca-Cola has impressive marketing expertise, is identified as a key external opportunity. According to beverage digest, "Coke went through two challenging years, but it is now emerging as a focused, well managed company again."15

I would give Coca-Cola a buy recommendation because the stock is well below its 5-year highs and appears to be trending up. Management looks good, and the 11,500 customers in 200 countries who sip a Coke beverage every second give me confidence that the company will see better days ahead. 


\section{$\underline{\text { References }}$}

Note: Data, references and graphs used by permission from Hartogh, et. al., "The Soft Beverage Industry", unpublished MBA study, California State University Northridge.

${ }^{1}$ Dow Jones Interactive online database. Company Profiles $>$ Coca Cola. Retrieved from www.library.csun.edu >databases. Apr 1, 2002.

2 "Coca Cola To Open 50,000 Outlets In Rural Push In India", Asia Pulse, Mumbai, Mar 22,2002.

Retrieved From www.library.csun.edu $>$ databases $>$ ASAP business $>$ Keyword: Coca-Cola, India.

${ }^{3}$ See Appendix A, Company Market Share 1997, 2001. (These are the latest figures we have retrieved.)

${ }_{5}^{4}$ See Appendix B, Company and Brand market share 2001. Beverage Digest.

${ }^{5}$ See the discussion on market fragmentation and beverage trends in Hartogh, et.al., "The Soft Beverage Industry" Unpublished MBA study, California State University Northridge.

See also, "Schools cash in as cola wars heat up", Chicago Sun - Times, Apr 21, 2002.

6 "PepsiCo Inc. Gains in Soda Market As Coca-Cola's Share and Sales Slip", Wall Street Journal, New York, Mar 1, 2002.

${ }^{7}$ www.sec.edgar.org > Company filings $>$ Coca-Cola Form $10 \mathrm{~K}$.

${ }^{8}$ See "Placing our bets. (Beverage Beat: overview of PepsiCo Inc.)", Beverage Industry, Jan 2002.

PepsiCo named "Company of the Year".

${ }^{9}$ Interview with Diana Lopez, Route manager, The Coca-Cola Bottling Company of Southern California (A controlling interest subsidiary of the Coca-Cola Company), Sylmar, California. Tel: (818) 362-4307 ext. 6307. Email:_diana_lopez@na.cokecce.com Interviewed on Apr 24, 2002.

10 "Repairing the Coke Machine", Business Week, Mar 19, 2001. Retrieved from http://www.businessweek.com on 4/15/02.

11 "Behind the Coke Board's Refusal to Let CEO Daft Buy Quaker Oats", Wall Street Journal, Nov 30, 2000.

12 "How Coke Pushed Rivals Off the Shelf", New York Times, Aug 6, 2000.

13 "Repairing the Coke Machine", Business Week, Mar 19, 2001. Retrieved from http://www.businessweek.com on 4/15/02.

14 "Coke Adds Life to Sales, Profit After Losing Fizz in Late '90s; Outlook for drink company brightens with restructuring and U.S. economic recovery", The Los Angeles Times, Apr 10, 2002. 
Appendix A Company Market Share, U.S.
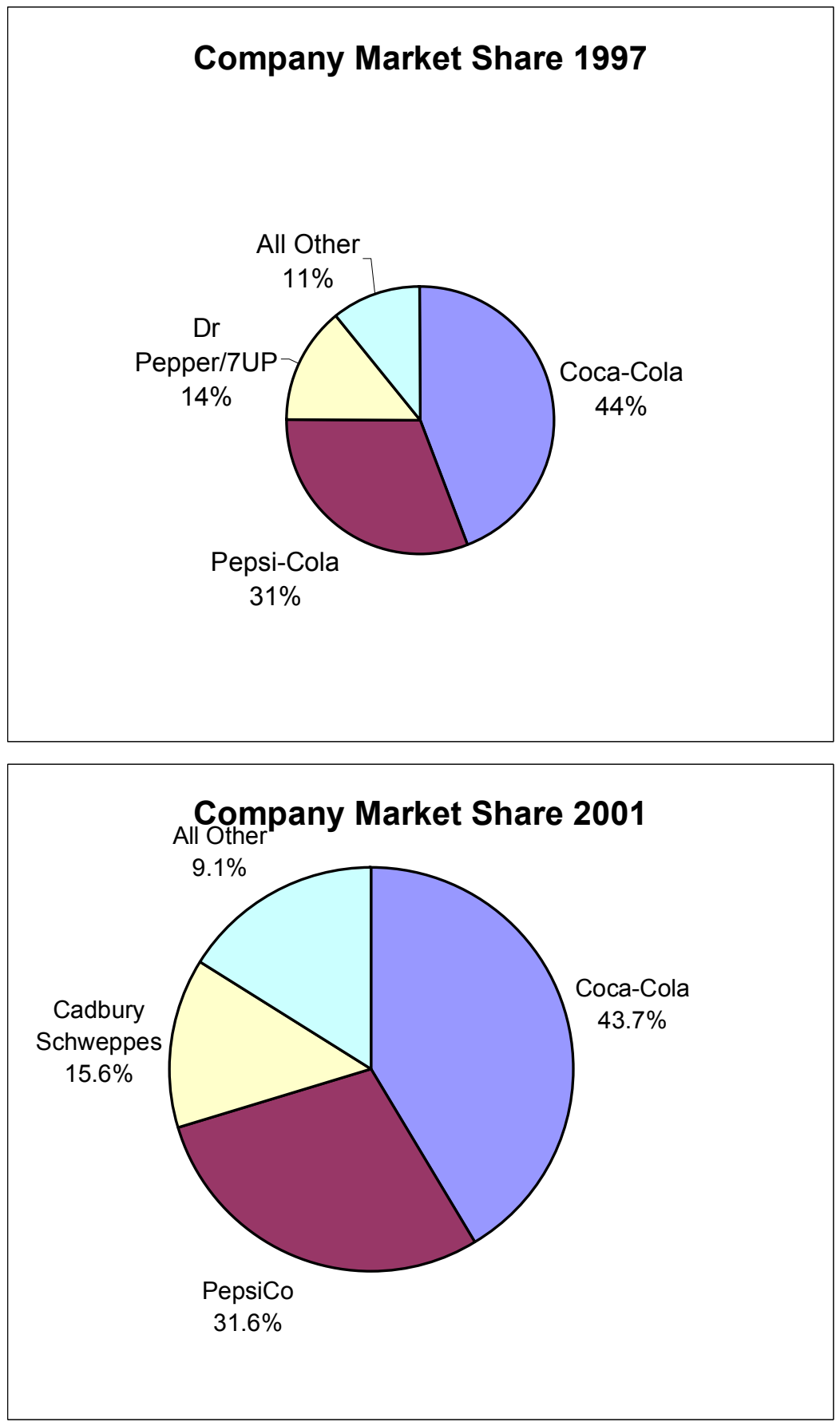

Source: Beverage Marketing Corporation, New York. Retrieved from http://www.beverageworld.com > "data and statistics" on 4/10/02. 
Appendix B Company and Brand market Share

$\begin{array}{cccll}2001 & 2001 & \text { Share } & \begin{array}{l}2001 \\ \text { Cases }\end{array} & \begin{array}{l}\text { Volume } \\ \%\end{array} \\ \text { Ranking Companies } & \text { Share } & \text { Change } & \text { (millions) } & \text { Change }\end{array}$

1. Coca-Cola Co.

$\begin{array}{llll}43.7 & -0.4 & 4,376.7 & -0.2\end{array}$

2. Pepsi-Cola Co.

$\begin{array}{llll}31.6 & +0.2 & 3,164.7 & 1.3\end{array}$

3. Dr Pepper/Seven Up

(Cadbury)

4. Cott Corp.

$\begin{array}{llll}15.6 & +0.9 & 1,559.9 & 6.4\end{array}$

5. National Beverage

$3.8+0.5$

$376.0 \quad 14.6$

$2.2+0.1 \quad 224.5 \quad 5.1$

6. Big Red

$\begin{array}{llll}0.4 & \text { flat } & 41.7 & 3.0\end{array}$

7. Seagram

$\begin{array}{llll}0.3 & \text { flat } & 30.4 & 6.7\end{array}$

8. Red Bull

$0.1+0.1$

$10.5 \quad 118.8$

$\begin{array}{llrr}0.1 & \text { flat } & 8.6 & 8.9\end{array}$

10. Private Label/Other

$\begin{array}{llll}2.2 & -+01.4 & 216.9 & -38.6\end{array}$

Total Industry

100.0

$0.0 \quad 10,010.0$

0.6

SOURCE Beverage Digest/Maxwell

$\begin{array}{rllll} & & & 2001 & \\ & & & \\ \text { Market } & \text { Share } & \text { Cases } & \begin{array}{l}\text { Volume } \\ \%\end{array} \\ \text { Brands } & \text { Share } & \text { Change } & \text { (millions) } & \text { Change }\end{array}$

1. Coke Classic

$\begin{array}{llll}19.9 & -0.5 & 1,987.5 & -2.0\end{array}$

2. Pepsi-Cola

$\begin{array}{llll}13.2 & -0.4 & 1,320.1 & -2.8\end{array}$

3. Diet Coke

$\begin{array}{llll}8.8 & 0.1 & 878.8 & 1.7\end{array}$

4. Mt. Dew

$\begin{array}{llll}6.9 & -0.3 & 687.7 & -3.9\end{array}$

5. Sprite

$6.5-0.1$

$646.2-1.8$

6. Dr Pepper

$6.2-0.1$

$617.0 \quad-1.7$

7. Diet Pepsi

5.3 flat

$533.6 \quad 2$

8. 7UP

$1.9-0.1$

189.2

$-7$

1.7 flat

171.7

$-1$

10. Barq's root beer

1.1 flat

114.2

1.5

SOURCE Beverage Digest/Maxwell 


\section{Appendix C Coca-Cola 5year Stock Price}

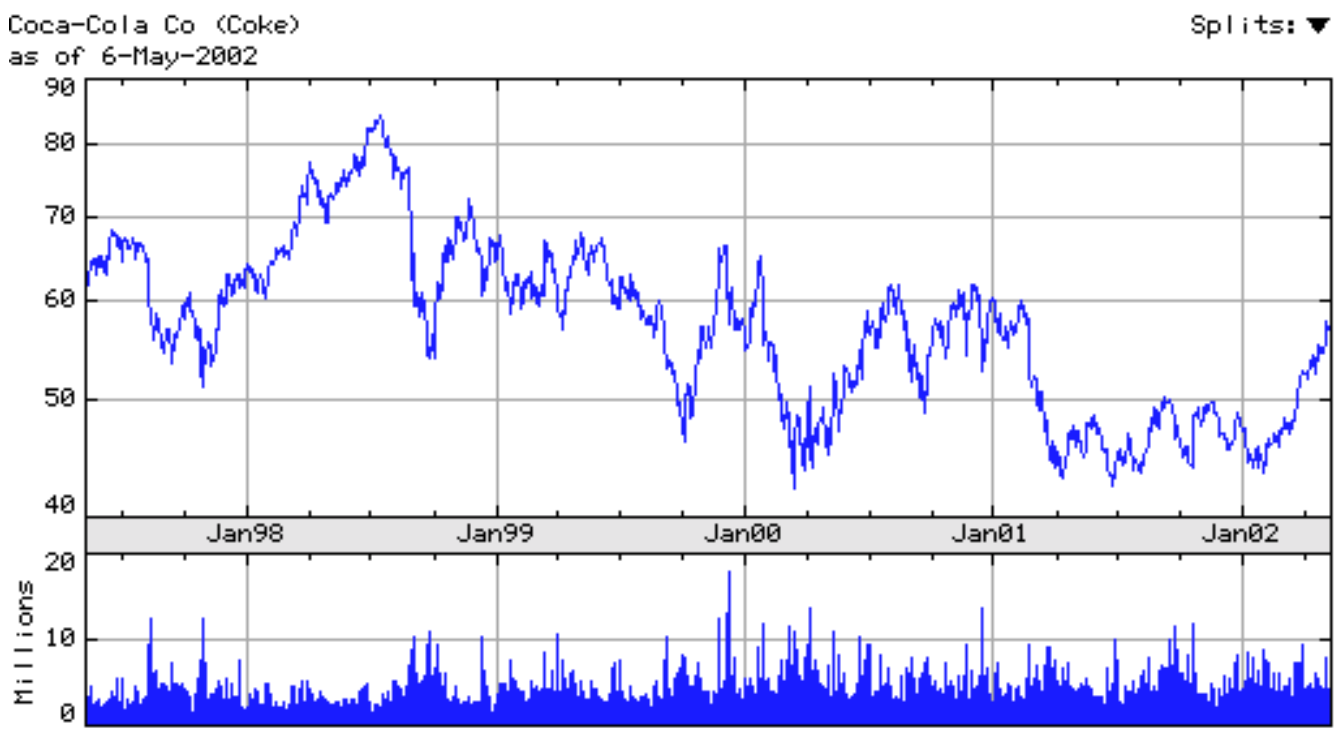

Copyright 2002 Yahoo! Inc.

http://finance.yahoo.com

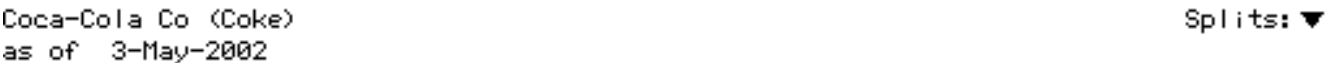

as of 3-May-2002

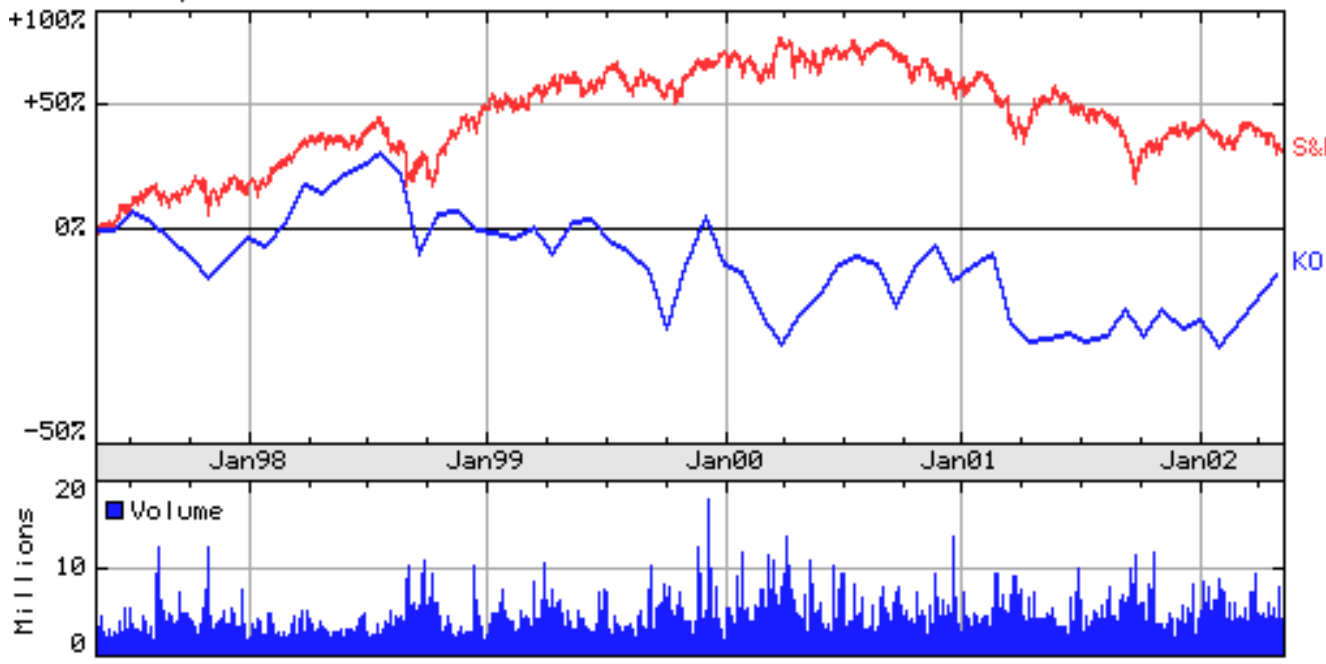

Copyright 2002 Yahoo! Inc. 


\section{Appendix D Coca-Cola 3 month Stock Price}

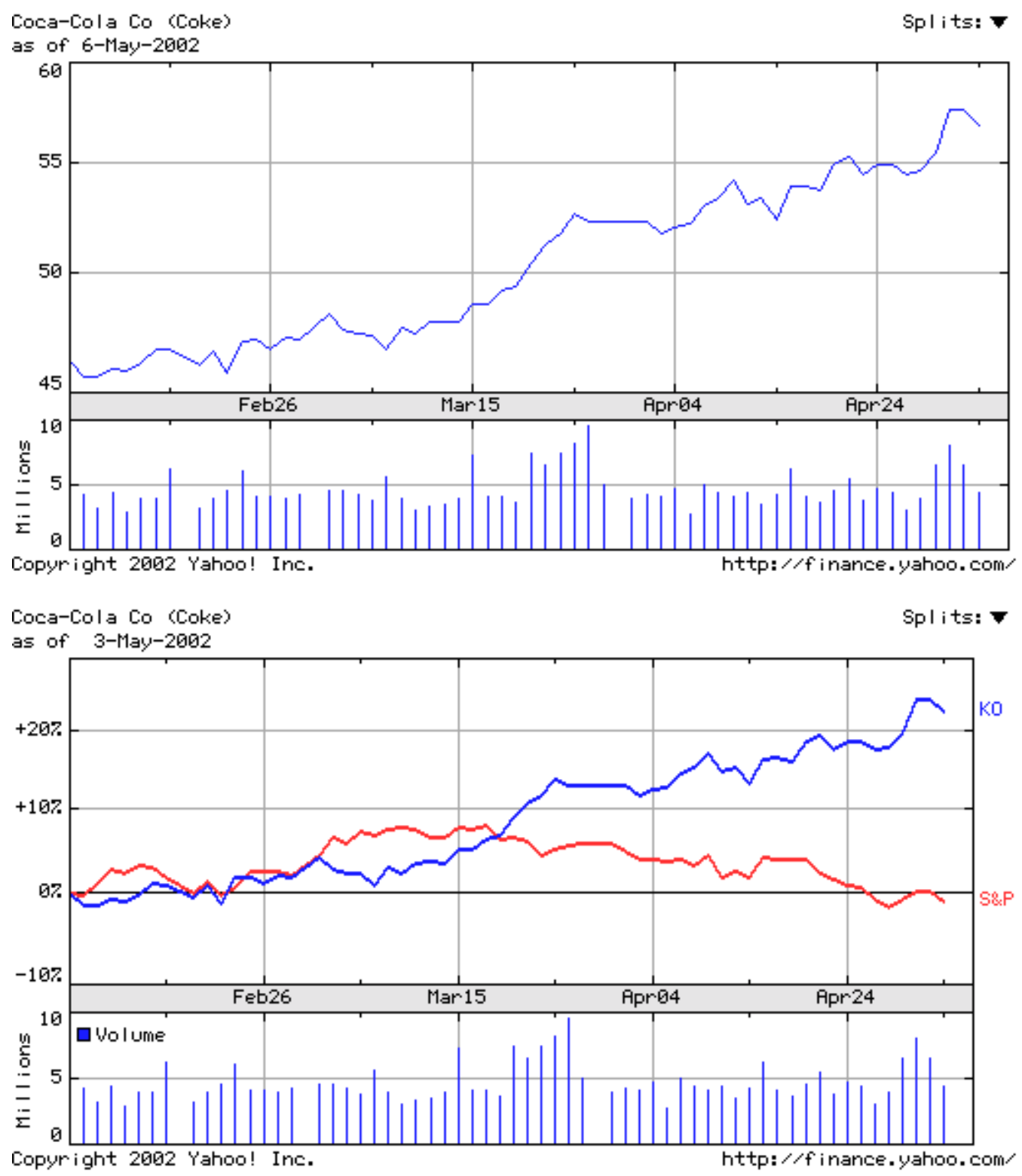


I have read and understood the CSUN policy on academic dishonesty, printed in the schedule of classes and in this coursepack. I verify that all of the work I submit in the program will be my own (in the case of individual assignments) or of my group (in the case of group assignments) and that all references to other sources will be properly cited. I understand that this assignment will become part of my student file here in the College 